\section{The tragedy of the false larch}

I recently received the April 1984 issue of Oryx, most interesting and informative as usual.

Under 'Briefly...' I found a note with the heading 'A tree loses some protection' referring to what amounts to a death-blow dealt to Fitzroya cupressoides (false larch) at the Botswana CITES meeting.

I think this case deserves comment on two grounds: the significance of the species in question and the way the Botswana decision was arrived at. Let me just say this:

(1) Fitzroya cupressoides is not just 'a tree'. It is, together with the North American Sequoia species, the longest-living tree in the western hemisphere, possibly in the world. It is known to reach at least 4000 years of age. If there is a monument of the vegetable world, to be respected and protected, this is it.

(2) This venerable species not only loses some protection'. It loses all of the little protection it had. For good reasons $F$. cupressoides had been on Appendix I of CITES right from the beginning: its populations, limited to the southern parts of Chile and Argentina, have been so reduced by burning and heavy exploitation that, considering the very difficult and slow regeneration of the species, it has been put on the verge of extinction. The Botswana decision pushed it over the brink.

(3) The death sentence for $F$. cupressoides was arrived at in a most irregular way. The proposal submitted by the Chilean Government to the Conference was to eliminate from Appendix I 'the dead specimens of $F$. cupressoides'. Under CITES this could not be done, so rejection of the proposal was certain. Beside this legal reason, there was abundant evidence in the hands of IUCN, WWF and many other non-governmental organisations showing the so-called facts and arguments of the proposal to be wrong and biased. What happened? At the last moment, during the final day of the Conference, when most of the delegates had already left or were busy preparing their departures, the proposal was altered, infringing all CITES rules, by substituting 'the coastal populations' for 'the dead specimens' 250 and was then adopted without anybody practically paying any attention!

(4) So the count-down for the exit of this 'old man tree' has begun. The loggers are rubbing their hands. If there had been scarcely any control before, now there is none: logging operations are in full swing throughout the last stands of $F$. cupressoides, 'coastal' and 'non-coastal' (in this country of an average width of 100 miles - 160 $\mathrm{km}$ - no line can be drawn anyway between ranges), exporting wood to the US with a permit granted on the strength of the CITES decision.

Godofredo Stutzin

President of Honour, Comite Nacional Pro Defensa de la Fauna y Flora (CODEFF), Casilla 3675, Santiago, Chile

\section{No name change for Gunung Mulu}

It seems there is a rumour about that we are planning to change the name of Gunung Mulu National Park to the Baram International Park. In fact there are no such plans. The proposed Baram International Park, sometimes known as the Baram River Club, is on the Usun Apau Plateau near the upper Baram River about 75 miles south of Gunung Mulu. It is largely a private venture and few details are available at present.

The fully protected areas of Sarawak are:

1. Bako National Park-27 sq km, gazetted 1957.

2. Lambir Hills National Park-69 sq km, 1975.

3. Niah National Park-31 sq km, 1974.

4. Gunung Mulu National Park-529 sq km, 1974.

5. Similajau National Park-71 sq km, 1979.

6. Gunung Gading National Park-54 sq km, 1973.

7. Samunsam Wildlife Sanctuary-61 sq km, 1979.

8. Lanjak-Entimau Wildlife Sanctuary-1688 sq km, 1983.

Seven other areas are under active consideration by the National Parks and Wildlife Office of the Sarawak Forest Department for either parks or wildlife sanctuaries.

Paul Chai P.K. for Director of Forests,

Sarawak

Oryx Vol 18 No 4 